\title{
Acceptance of Christianity in Iceland in the Year 1000 (999)
}

By Jónas Gíslason

\section{An attempt at explanation}

It is difficult to provide a comprehensive analysis of the acceptance of Christianity in Iceland in a short essay and therefore, only a short précis of the Christianization of Iceland and its pre-history will be given here. The main aspects of the history of the formal acceptance of Christianity will be included, together with an appraisal of whether the commonly adopted interpretation of the pre-history of Christianity will stand. Finally, an attempt will be made to explain how the conclusions recorded by history came about.

(In this paper, the year 1000 will be accepted without regard to the school of thought which accepts the year 999 as the year that Christianity was promulgated in Iceland.)

\section{The beginnings of settlement in Iceland}

The history of the acceptance of Christianity in Iceland has often caused astonishment, and the question has been posed: How is it possible that Christianity was promulgated in this way in the Althing (the early Icelandic parliament), when heathens were in the majority. The only response has been to place a mysterious $x$ over this event.

Obviously, something is lacking in this explanation; it will not withstand critical analysis. The brevity of the Scandinavian mission in Iceland in no way accounts for the strong position of Christianity in the country at the close of the tenth century. It is not known with any certainty what the population of Iceland was at this time, but it has often been estimated that is was about one fourth that of Norway. There is no possibility that an extremely small group of men could have converted a population of this size in such a short period of time.

It has been customary to consider the settlement of Iceland to have begun with the arrival of the Norsemen, starting in 874, although this date is, mildly stated, doubtful. There are various indications that 
the Nordic settlement began shortly after 800 , although this assertion will not be given greater consideration here.

What is certain, is that the earliest Nordic settlers encountered Irishmen when they first set foot on Iceland; these Irishmen were hermits and monks, 'papar' (Íslendingabók 1968, 5; Landnámabók $1948,1)$. It is impossible to say how long these men had been living in Iceland.

Various sources mention voyages to the islands and countries in the far northern seas; the most ancient is that of Pythias of Marseilles in France, although it is uncertain which lands and islands he visited.

Then there are reports of voyages by the Irish in the northern seas, including Iceland (Navigatio 1973; Dicuilus 1967).

Various circumstances could have brought the Irish north to Iceland. They seem to have had, in common with other island peoples, a strong desire to journey abroad. This urge to travel accorded well with their interest in missionary work, as did the interest many of them had in pursuing the anchorite life in isolated places where they could concentrate on the worship of God; and, of course, anchorism and asceticism were widespread in Ireland. During this period, the Irish Church flourished and carried on intense missionary activity on the continent.

This could explain the voyages of the papar to Iceland. It may be considered likely that they began to settle in Iceland shortly after the Faroe Islands were colonized, or early in the seventh century, though it was hardly likely to have been a large group of anchorites at the beginning.

A period of decadence in Irish monastic life, characterised by increased concern with worldly matters, seems to have occurred in the eighth century, and this led to a decline in religious observance.

Subsequent to this period of decline, there developed a new kind of Irish anchorite which placed greater emphasis on asceticism than on learning. These monks were called 'kúldear' (Céli Dé) or 'servants of God'; it is to be noted that these reformers sought seclusion on isolated islands.

With the Viking invasions of Scotland and Ireland around 800, flight to distant places where the populace could be more secure from the incursions of the Vikings doubtlessly occurred. It is probable that the papar retreated to Iceland and established settlement based on the Irish model. There are various indications that such Christian settlements continued despite Nordic colonization. 
There are two written sources which mention the stay of the papar in Iceland:

One is Íslendingabók, which states:

At that time Iceland was covered with woods between the mountains and the sea. There were Christians here, those the Norsemen call papar, but they left later, because they didn't want to be here with heathen men, and they left behind Irish books and bells and croziers; from this it can be concluded that these men were Irish (İslendingabók 1968, 5).

In the introduction to the Sturla version of Landnáma is the following:

But before Iceland was settled from Norway, there were men there that the Norsemen call papar; they were Christians, and it is thought they had come here west across the ocean because of Irish books, bells and croziers and other things which led people to believe they were Westmen (i.e., Irish). It is also mentioned in English works, that, at that time, there was travel between the two lands. (Landnámabók 1948, 1).

Ancient texts mention nothing further about the first inhabitants of the country; and this is surprising, because the author of Íslendingabók, Ari frodi (Ari the Learned), was a priest and could have been expected to have had greater interest in these early settlers.

Íslendingabók was composed at the behest of the Icelandic bishops during the twelfth century, and the Roman church seems to have been interested in proving that Christianity in the West had come directly from Rome and at the instigation of the papacy; thus it would be expected that the Roman church had little interest in protecting the memory of a church which had, for a period of time, competed with it for the leadership of Christianity in Western Europe.

It does matter that Ari does not seem to have been faithful to events in his account of the papar where he mentions that they left Iceland. It would be surprising if the Nordic settlers had, without objection, allowed them to leave at the same time that they were harrying Ireland in order to obtain slaves. Wouldn't it have been easier to enslave the papar already on Iceland?

And, where could the papar have gone if they left Iceland? Hardly to Ireland which was to a great extent under the control of the Norse vikings. The only lands to which they could have fled were Greenland and America, but there is no known voyage to these places from Iceland so early on. 
What is more likely is that the Irish in Iceland were variously killed, captured and enslaved, or that they fled the Norsemen and settled in isolated parts of the country or in those places where a Christian community already existed. The books, bells and crosiers which they left behind must have been essential to their daily religious observance. Men who had to leave such belongings behind hardly had time to prepare their departure, but of course, the papar were most likely fleeing the vikings.

It is probable that some of them fled to the west Fjords which scarcely seem to have been settled then by the Norse; many place names are found there which reflect Christian influence. In addition, very few heathen graves have been found there.

\section{Nordic Settlement in Iceland}

As was mentioned above, the Norse settlement of Iceland most likely began in the early part of the ninth century. The main source of information about it is Landnámabók, written in the thirteenth century, and place names seemingly had a significant impact on the text. In addition, the authors of the work had direct interests to protect, as they did not wish to demonstrate the likelihood that their ancestors played a significant role in the settlement of the island.

A very specific delineation of the limits of settlement is given for each settler. It is important to remember that the colonization of Iceland was an uncoordinated individual initiative and that chance often dictated where land was taken.

It was the custom of the Norsemen when they appropriated land to allow the original inhabitants to continue to live on the land, subject to the direct control of the Norse. Generally they sailed only to already settled lands where there was likelihood of gain.

Most of the first settlers had Nordic names, although there are examples of Celtic names. It is interesting to note that most of the latter were of the same lineage, decendents of Ketill flatnefur (Flatnose), the son of Bjarni buna (the Spurt), who had lived in the Shetlands, though others are named as well.

When attention is paid to where they (those with Celtic names) took land, it seems clear that this is in the same area where the fewest heathen graves have been found; it seems likely that the kernels of Christian settlements developed at these locations. The chief of these were: 
1. Akranes, Kjós and Kjalarnes.

2. Dalir.

3. Pappýli at Sída in the east

In addition, there are various indications that Christians lived on the southern part of the east fjords and in the west fjords, as both locations have place names with Celtic equivalents.

Two explanation are worth considering for the existence of these Christian districts:

1. Christian colonists settled there along with their retinue; papar and other Irish could have removed to these areas when they were forced to flee the heathens encroaching on their previous dwelling places.

2. The other possibility is that these were Christian communities before the Norse settlement and that they continued to exist, possibly because the Christians were sufficiently powerful to defend their control, or because these were districts which were settled at a later time by Christians or heathens who practised a blend of the two religions and were, consequently, more lenient toward practitioners of Christianity.

It is mentioned that heathens were not permitted to live at Kirkjubær at Sída, and all attempts by the heathens to take control of that area met with defeat; attacks which conclude with the successful defence of Kirkjubær by the Christians are described.

Undeniably, it would be surprising if the heathen settlers had been more lenient in their treatment of Christian colonizers than they were toward other Christians. And it is clear that at the Althing of 930 the entire power structure of the country was intended for practitioners of heathen beliefs, and that the Christians obtained no part in the governance of the country.

The position of Christians in the governing structure of tenth century Iceland was, therefore, quite weak.

\section{a. Pagan Belief in Iceland during the tenth century}

An attempt to elucidate the position of the pagan religion in Iceland during the tenth century must be made.

Landnámabók states that Iceland was completely heathen for nearly 120 years (large 100) (Landnámabók 1948, 396). According to this then, Iceland ought to have been completely heathen far into the tenth century. 
Such an assertion can hardly stand. Some of the first colonists survived into the tenth century and it would be unbelievable that the sons of these Christians denied their faith, although the possibility of power doubtlessly tempted some of them. Christianity spread throughout northwestern Europe, and the Icelanders had significant contacts with those countries; there are allusions to various Icelandic chieftains who allowed themselves to become catechumens, without being baptized, during their voyages in order to be able to have complete intercourse with Christians. This applied to whole crews of Icelandic vessels and these men must have been under Christian influence to a greater or lesser extent.

Then there is mention of various Icelanders who accepted Christianity during the tenth century; and, it is added this was done abroad. It is probably highly likely that this explanation was offered to prove the assertion that the country had been totally heathen at that time. Finally, it ought to be mentioned that the Norse Mission to Iceland began in 980 .

On the other hand, it seems clear that power was in the hands of the heathens and the nickname Ketill the Fool indicates that his missionary activity was considered foolish.

Only the Icelandic chieftains have been considered here, and of course the Icelandic sagas are the literature of chieftains; ordinary people and slaves were not considered, except as foils for the story of the chieftains. Whether the Irish were more or less numerous before the Norse settlement, there was at that time a substantial group of Irish slaves, male as well as female, who were Christian. And, it bears mentioning that it was the traditional function of slaves to supervise, to a greater or lesser extent, the upbringing of the children of the chieftains; that would have had its influence on the decline of the role of heathendom in the tenth century and would also have prepared for the change of religion in the year 1000 .

Information about heathen beliefs in the tenth century is extremely scarce; and, of course, most of the sources for these beliefs were written down by Christians and at a later date, or they were written by men who were under strong Christian influence. It seems clear, however, that the asatrú was first and foremost a "kultus", the performance of specific religious ceremonies. Men seem to have made some sort of agreement with the gods; specific services and deeds would be performed for the gods in return for their protection and reward. If either of the parties to the agreement failed to fulfill his obligations, the other was absolved of all responsibility. This so called ásatrú can 
hardly have had as developed a religious doctrine as has sometimes been maintained.

A more doubtful matter is how strong an influence the ásatrú had among the ordinary folk; there are many indications that all kinds of superstition and belief in spirits were widespread.

Christianity is the religion of the book, of the Bible. It is not merely the performance of outward religious observance, but first and foremost the profession of belief in Jesus Christ and the observance of his teachings.

It is, however, necessary to point out that it is difficult to determine the content of Christian missionary activity at this time, although there are certain indications that the people were taught various primary tenets of Christian belief. The main emphasis was doubtless placed on assuring the people that Christ was more powerful than all the old gods; Christ the victorious was taught, the Christus victor who had destroyed the power of evil.

It is no less clear that the Christian mission was aimed above all at the chieftains as was the custom among the Germanic groups; the family and retinue followed the example of the Chieftain. It was the Icelandic chieftains who made the decision at the Althing that all Icelanders should accept Christianity and be baptized; the desires or the attitudes of the people were not consulted or considered.

Most scholars agree that the position of heathendom in Iceland was relatively weak at this time. It is difficult to move locally dependent beliefs between countries, as ghosts are considered to exist in a particular stone or cliff and would most likely be loath to follow their worshippers.

It may be concluded that this was, in general outline, the position of pagan belief in Iceland in the tenth century, Christianity existed in limited areas of settlement and among a part of the lower classes of society. Among these must have been ordained priests because Christianity could not have survived without the necessary ecclesiastical services, though this is not mentioned by any of the authorities.

But, the Christians were a politically powerless minority in a country where all such power was in the hands of the heathens. 


\section{The Nordic Mission in Iceland}

\section{a. Thorvaldur vídförli (the Widely Travelled) Kodránsson}

There is no mention in the sources that the papar or other Christians made any direct attempt at missionary activity among the Norse in Iceland before 980 . Neither did the Roman church make any effort at missionary activity in Iceland. The first endeavour at direct conversion by the Norse in Iceland was, according to the authorities, the personal initiative of one individual.

Thorvaldur, the Widely Travelled, Kodránsson went abroad as a young man, campaigning according to the custom of the Norsemen and winning fame for his abilities. He went south to Germany, where he became acquainted with the Saxon missionary bishop, Frederic, who converted him. Thorvaldur then wanted to return home to Iceland to proclaim the new belief to his kin and friends, and Frederick accompanied him (Kristnisaga 1905, 1). They arrived in Iceland during the autumn of 981 and spent the winter with Kodrán, Thorvaldur's father.

At first Kodrán wanted to know nothing about their religion, and he kept firmly to his ancient pagan beliefs. Kodrán was, however, present at the celebration of Mass on a feast day, "more out of curiosity" and he was moved by the ceremony of the Christians which he found surpassed the religious practices of the heathens. Father and son spoke together and Kodrán said that Bishop Frederick seem to be Thorvaldur's soothsayer:

... because I know that you receive from him all those things that you preach to us on God's behalf; but I have another soothsayer that is very useful to me... He lives a short distance from my farm in a stone both great and noble.

Thorvaldur answered:

You call your soothsayer very strong and say you have great trust in him; the bishop, whom you call my soothsayer, is not of great strength; but if he through the might of the God of the heavens that we believe in, is able to drive your soothsayer from such a stronghold, then it is right that you abandon him and turn to the strongest God, your creator, who is the one true God over whom no power can be victorious (Dáttr Dorvalds 1905, 65 f.).

Kodrán agreed to this. The next day the bishop blessed the stone by sprinkling holy water on it. This action was repeated for three days; 
the soothsayer in the stone came to Kodrán each night and complained about this behavior. Finally he said:

'Now we must sever both our association and our ties of friendship, as you have rewarded me evil for good.' Kodrán answered: 'I have worshipped such a strong and useful god, while I was unaware of the true God, but now that I have proved you deceitful and very helpless, it is right for me to desert you without any impropriety on my part and to flee to the protection of that godhead, which is much better and stronger than you' (Páttr Porvalds 1905, $67)$.

Kodrán then had himself and all his people baptized except his other son.

Though this account carries a considerable air of pious legend, one can suppose that the main outlines conform to actual events. Thorvaldur and the bishop preached belief in Christ the victorious, who was mightier than the old gods. They remained in the country four years, travelling throughout the north and west, and converted several chieftains to Christianity; others became catechumens and could, in this way, have intercourse equally with both Christian and heathen men.

They also went to the Althing and preached Christianity there, but met with great resistance. The pagans lampooned them:

Children have been borne/of the bishop nine/of them all/

is Thorvaldur father (Páttr Porvalds 1905, 73).

Thorvaldur became angry and killed two men who had composed the ditty, but the bishop objected to this action since Christians ought not to seek revenge.

The group went to the district Thing at Heganes to proselytize, but were forced to leave. They were probably banished from Iceland at this time, as they left the country the following spring.

With their departure, this attempt at Christianizing Iceland ended and Bishop Frederick vanishes from Icelandic history.

Thorvaldur never returned to Iceland. He went to the Holy Land and from there to Constantinople where he entered the service of the emperor. He was said to have been made the supreme monarch of Russia; Christianity was accepted in the Ukraine in 988 . It is mentioned that Thorvaldur died in a monastery which he established in Russia and was buried there (Páttr Porvalds 1905, 78 f.). 
The story of Thorvaldur raises various interesting questions to which it is difficult to find answers. At about this time, the disagreements which led directly to the schism of 1054 arose between the eastern and western branches of the Church.

It is conceivable that Bishop Frederick was a missionary bishop from the eastern Church. He did not speak a Nordic language, so Thorvaldur had to interpret for him; Norse was spoken over the whole of northwestern Europe at that time.

If this is correct, then it is more understandable that Thorvaldur should go east, which was however the direction generally taken by the Nordic vikings, particularly the Swedes. Reasonable connections with the "Armenian bishops" who travelled to Iceland after the middle of the eleventh century could also have developed in this way. These men "preached more feeble Christianity than the others and became popular because of this among bad men" (Hungrvaka 1905, 92). This assertion cannot be proved with evidence currently available.

The same year that Thorvaldur and the bishop were expelled from Iceland, there is mention of other expulsions. Erik the Red removed to Greenland with a large group of people in a total of twenty five ships. Only fourteen of the ships arrived in Greenland. The others either had to turn back or were lost (Landnámabók 948, 126).

Is there a possible connection between these two events? There is no way to answer this question, but it is possible to indicate certain particulars which lead to this conclusion.

1. Thjódhildur, the wife of Erik the Red, was a Christian and had a church built upon her arrival in Greenland.

2. With the acceptance of Christianity, little is made of those who had accepted the faith from Thorvaldur and his companions. What happened to them?

3. Was it primarily Christians who moved to Greenland? It is interesting to note that no heathen graves have been found in Greenland although history maintains that Christianity first appeared there fourteen years later, or in the year 1000. It is known that many ships and a large number of people were lost on the voyage. Were all these Christians?

If such were the case, then both situations probably applied: those who had accepted the faith from Thorvaldur and the representatives of his type of Christianity which had existed in the country from the time of the papar. It might also well be that men other 
than Thorvaldur and Bishop Frederick suffered persecution and had been driven out of the country.

4. Breidafjördur was the point of departure for the voyage to Greenland and one of the sites of the Christian community in Iceland had been in Dalir near Breidafjördur.

If a group of Christians from this area were forced to flee the country, the Christian chroniclers of a much later date would hardly have had any interest in preserving the memory of such persecution.

It is of course difficult to draw this conclusion from available evidence, and other explanations are conceivable. It is possible, for example, that this group left in order to avoid the problems of overcrowding; Iceland is considered to have been almost fully populated by this period.

The hypothesis that Greenland was settled later than has been considered, or just a few years before the formal acceptance of Christianity has also been put forward (Halldórsson 1978, XV).

There is, at present, no answer to these questions, but it seems impossible to avoid posing them. It should be mentioned that at the archaeological research site at Herjólfsnes signs of Celtic burial rites have been discovered, and this indicates that followers of Irish Christianity buried their co-religionists there.

\section{b. Stefnir Thorgilsson}

After the departure of Thorvaldur and his companions, there seems to have been a hiatus of a decade before missionary activity was renewed on Iceland. And, it was no longer the attempt by an individual acting on his own. A new actor had entered the story of the conversion of the Icelanders, Ólafur Tryggvason, the King of Norway; he could augment his influence on Iceland if its inhabitants accepted Christianity.

After the manner of the Vikings, King Ólafur directed his interest to those islands which the Norse had occupied; and of course, he considered himself to have specific obligations to fulfill with regard to these people. In addition, he no doubt had dreams of establishing a powerful kingdom, which would include, in addition to Norway, the islands of the North Atlantic.

An Icelander, Stefnir Thorgilsson, was a member of King Ólafur's retinue; he was considered the self evident choice to undertake a mission to Iceland. He was reluctant to take on the work, but was moved to comply after an exchange of words with the king (Olafs saga 1958-61, 1, 309 f.). 
Stefnir must have arrived in Iceland during the summer of 996 and immediately begun his missionary activity, but his mission was badly received. This angered him and he attacked with severity; it is said that he travelled around the country with ten men and took "to harming temples and the altars of stone, and breaking idols" (Kristnisaga $1905,17)$.

This behaviour was, as is to be expected, badly received by the heathens who took up arms. Stefnir immediately realized the hopelessness of his situation and fled to the protection of his uncles at Kjalarnes.

At the Althing the following summer, a law was passed which stated that a man was to be outlawed if he blasphemed against the gods or harmed them. Christianity was called an offence against the family or clan, and was to be prosecuted by relatives between the third and fifth degrees of kinship. This legislation is interesting and shows that the heathen considered themselves hard pressed when they were attacked at the root of the clan (family). Missionary activity alone can hardly explain so severe a reaction.

A likelier explanation is that Stefnir had other commissions in additions to his mission of conversion and that he attempted to submit the Icelanders to the power of the king. When neither errand met with success, Stefnir reacted with intense anger and took to "breaking up temples and places of worship".

Stefnir was later outlawed in accordance with this law. He returned to Ólafur's court and reported that it would be slow work to convert the Icelanders to Christianity.

There do not seem to have been any particular results from Stefnir's journey; but, on the other hand, one might conclude that the Icelanders realized that a new leaf had been turned in the Christian mission to Iceland. The king of a foreign country had attempted to influence Iceland, and he was unlikely to allow the situation to rest with this one attempt.

\section{c. Thangbrandur the Priest}

King Ólafur did not give up. He sent a new missionary to Iceland that same summer: Thangbrandur, a German adventurer, who had been in the service of King Ólafur in England. He had become a priest in Norway, but took to harrying the heathens in order to plunder them. Consequently, the king no longer wanted to have him in his service. Thangbrandur requested asylum and offered to take on a difficult task 
for the king as a penance, and the king sent him to Iceland (Kristnisaga $1905,17)$.

Thangbrandur landed in the eastern fjords in the midsummer of 997 and went directly to meet with Hallur at Sída, one of the most important chieftains in the east, who invited him to winter at Sída.

It is mentioned that Thangbrandur celebrated mass as early as the second day after his arrival:

Hallur went and his domestics with him to see their actions and they heard the ringing of bells and detected the perfume of incense and saw men decorated with fine woven material and purple. Hallur asked his domestics how they liked the actions of the Christians and they approved.

Hallur was baptized the Saturday before Easter and all his people there in the river, which has been called Thvottá (the River of the Cleansing) ever since (Kristnisaga 1905, 21).

Hallur of Sída became one of the major participants in those events which two years later led to the acceptance of Christianity at the Althing. It is likely that Hallur's acquintance with Christianity was greater or of longer duration than is depicted in the sources, and it is unlikely that Thangbrandur could have been his spiritual father, so deep an understanding Hallur seems to have had of the Christian religion according to the sources - a much deeper understanding than Thangbrandur himself had - is also unlikely. Hallur is practically described as being a holy man; this could undoubtedly be the result of the influence of the tradition of saintly legends, in addition to which, Ari the Learned, the author of Íslendingabók, was a fourth generation descendent of Hallur as will be mentioned later in this essay.

The following summer, Thangbrandur began his travels around Iceland; and, in the manner of King Ólafur, he brandished his sword in pursuing his mission. The accounts of his jorneys are somewhat confused and it could sometimes be supposed that they were set down from place names. These records can hardly be credited, as his stay was shorter than the records account for, or only two years, 997-999.

Thangbrandur seems to have ridden in the company of Hallur to the Althing. They had given themselves more than enough time for their journey, and stopped often to preach the faith; and the results were astonishingly great. The sources maintain that he baptized four chieftains on his way and that two others became catechumens (Brennu-Njáls saga 1954, 258 ff.).

It is likely that these converts were friends of Hallur. Despite this, such achievements must be considered incredible just one year after 
Christianity was made a legal offence against the clan. One would expect that Thangbrandur had achieved these results in an even shorter period than mentioned, that he succeeded in accomplishing this during a relatively speedy trip to the Althing, as they could hardly have stopped for any length of time at each farm. Nowhere is it mentioned that Thangbrandur revisited these men to inform the converts more thoroughly of the tenets of the faith or to secure them in their faith; but such has been the universally acknowledged method of Christian missionaries from the days of the Apostle Paul to our time. This achievement must be considered nearly unique in the history of Christian missionary activity, if what is chronicled is accurate.

The sources mention that Thangbrandur visited a number of places and that he met great opposition among the heathens, some of whom he killed. It is stated that once some heathens got a magician to take Thangbrandur's life; as a result of the magician's assistance, the earth is supposed to have swallowed up Thangbrandur's horse, but he himself escaped completely unharmed (Kristnisaga 1905, 21). The basic elements of this story could easily be true. In violent rushes of glacial runoffs in the sands of the Skaptafell region, large floes of ice are often borne down onto the sands where they are covered by the sand. They then melt and subsequently form hollows under a shellthin covering of sand. When a rider travels over these areas, the shell breaks under the heavy weight of the horse which then drops into the hollow.

Thangbrandur's progress to the Althing was therefore to some extent strewn with blood, and it is amazing that such a peace-loving man as Hallur of Sída seems, according to descriptions of him, to have accepted such conduct. In addition, one might have expected the heathens to react violently to such overbearing behaviour.

Quite to the contrary, Thangbrandur was allowed to preach his religion at the Althing, and many must have accepted Christianity there. The heathens, on the other hand, were forestalled from avenging themselves on Thangbrandur for manslaughter because of the strength of those who supported him, especially Hallur of Sída and Njall of Bergthorshvoll, those peace loving chieftains who always wanted to adhere to the law (Brennu-Njáls saga 1954, 264). It is undeniably odd how much men had altered their opinions from the preceding summer.

After the close of the Althing Thangbrandur travelled east and then he continued north all the way west to the river Skjálfandi. Later in the autumn, he seems to have gone to the south by sea all the way west to Borgarfjördur where he was badly received, so badly that 
he even had to steal provisions (Kristnisaga 1905, 26). In the end, he went to Skalholt (Kristnisaga 1905, 27), where he wintered; he is said to have baptized Gissur the White as well as his people including, expectedly, his son-in-law, Hjalti Skeggjason - during the winter. Thangbrandur had most likely met Gissur at the Althing and accepted at that time Gissur's invitation to visit at Skalholt. From this point on, Gissur and Hjalti become responsible for leading the Christians, along with Hallur of Sída.

The following summer Thangbrandur seems to have travelled in the western part of the country, all the way up to Bardaströnd (Kristnisaga $1905,28 \mathrm{f}$.). He left the country early in the summer, before the opening of the Althing.

One would have expected that Thangbrandur was tolerably satisfied with his missionary journey to Iceland and its results, but quite the opposite was the case. He had nothing good to say of the Icelanders and "said there was no hope that Christianity would be accepted there" (Kristnisaga 1905, 34). This assertion by the sources significantly diminishes the credibility of the accounts of his journey. The question then arises whether the story of Thangbrandur isn't an attempt to explain the antecedent causes of the introduction of Christianity with two aims in mind:

1. to prove that Irish Christianity had had no concrete influence in Iceland

2. to show that King Ólafur had had the sole honour of bringing Christianity to Iceland.

Apparently, the account of Thangbrandur's travels does not at all withstand scrutiny. It is undeniably curious that he is made to pass precisely through those districts where Christians were most likely to be found. All those men who play an important role in the formal acceptance of Christianity are said to have been baptized by Thangbrandur. As was mentioned earlier, nothing is made of those who had been converted as a result of the work of Thorvaldur and Bishop Frederick.

Finally, the negativity of Thangbrandur's report of the situation among the Icelanders when he returned to Norway is, if true in other respects, completely incomprehensible. The reaction of King Ólafur indicates that he believed Thangbrandur's report and that he intended to take revenge on those Icelanders who were in Trondheim, as will be discussed later; King Ólafur considered it absolutely necessary to take drastic action against the Icelanders. It is clear that the achievement 
of Gissur and Hjalti, as well as that of Hallur, gains with the story of Thangbrandur as background; it could well be this which led to the story being recorded in the way that it was.

\section{The Acceptance of Christianity in Iceland}

\section{a. The transition to formal acceptance of Christianity}

After the departure of Thangbrandur, the leadership of the Christian community at the Althing of 999 was in the hands of Hallur, Gissur and Hjalti; discussion focussed, as was to be expected, on belief and men were very much divided in their positions. Now, the opposition of the pagans was much greater than it had been the previous summer; it seems to have been not unlike that of the summer of 997 , when Stefnir was found guilty of blasphemy and outlawed from the country.

Hjalti went the furthest of the Christians and lampooned the gods:

Vil ek eigi god geygja/grey thykki mér Freyja

(I have no desire to bark at/mock the gods/but Freyja (the goddes of beanty) seems to me a bitch/poor thing) (Kristnisaga 1905, 30; Íslendingabók 1968, $15)$.

This caused an uproar at the assembly. The heathens wanted to try Hjalti in accordance with the law of 997 , but their attempt to prosecute him met with the resistance of the Christians who seem to have become sufficiently numerous both to foil the intentions of the pagans and to hinder the Althing in its work; in fact, for a long time, no pagan was able to start proceedings. The pagans finally succeeded in getting their way by use of force; Hjalti was judged an outlaw and thus forced to leave the country or forfeit his life.

It almost seems that the Christians had instigated an insurrection at the Althing and had attempted to hinder the legal proccedings of that body, although, in the end, they failed. The pagans realized that they had to take more extreme measures in order to ensure their continued control of the country. They decided, for example, to delay the opening of the Althing by a week to ensure that there would be sufficient growth to feed the horses; because of the inexactness in determining dates, the setting of the Althing had, little by little, been moved forward so that it was often difficult to find grazing land for the horses of the thingmen who came on horseback to Althing; this affected most those who had to travel the greatest distance across the wilderness. 
The pagans were in the majority precisely among those men; the Christians seem, on the other hand, to have been relatively strong in those districts which were closest to the location of the Althing. The Christians also seem to have consulted with one another and prepared themselves for an anticipated attack at the next parliament, where a final decision could be expected as to who would control the country, the Christians or the pagans. Although the Christians were a minority among the chieftains, they were, nonetheless, so numerous that they could no longer be excluded from all participation in the governance of the country.

The Christians seem to have reached agreement on two matters.

1. They intended to get together that year at a specific time and place right outside the meeting site just before the opening of parliament and to ride from there in a body, accompanied by their supporters, to the Althing.

2. In addition, they seem to have decided to send a representative to Ólafur, the King of Norway. They were doubtlessly looking for his assistance in establishing Christianity in the country; his interest could hardly be questioned after the missions of Stefnir and Thangbrandur to Iceland. It is also possible that they considered it necessary to put their case to the king, particularly if Thangbrandur had explained the situation in Iceland and had represented them in not too kindly a light; considering what Thangbrandur had in fact told the king about the situation in Iceland, the Icelanders must have known about the king's harsh attitude toward their fellow countrymen. This indicates that Thangbrandur and the Christians in Iceland had quarrelled and that had, without doubt, hastened Thangbrandur's departure from the country before the convening of parliament, though, of course, such assertions are unprovable.

Hjalti was forced to quit the country as a consequence of the judgement against him: Gissur, his father-in law, decided to go with him. When they arrived in Trondheim, the king was very angry with the Icelanders because of Thangbrandur's report and was considering taking revenge on those Icelanders who were in Trondheim; included in this group were the sons and brothers of some of the leading Icelandic chieftains, among them, Kjartan Olafsson, the son of Olafur the Peacock, Svertingur Runolfsson of the Dale, his father was one of the foremost heathen leaders in Iceland, Kolbeinn Thordarson, the brother of Flosi at Svinafell, Halldor Gudmundsson, the son of Gudmundur the Rich from Mödruvellir, Thorarinn Nefjolfsson, Hallfredur the Troubled Poet 
and Bolli Thorleiksson, the foster brother of Kjartan Olafsson.

Both Gissur the White and Hjalti met with the king; Gissur was in fact related to him. They told the king a completely different tale about the situation in Iceland than Thangbrandur, and they spoke of Thangbrandur's wicked behaviour that he had "there as here, rather unwisely, killed several men and people found it hard to accept the faith from a foreigner" (Kristnisaga 1905, 35), and that they considered it more promising if an Icelander should undertake the mission, and this they offered to do themselves.

It is notable how significantly their report differs from that of Thangbrandur; and it is no less notable how badly they spoke of him, especially if he had been their spiritual father and had baptized them.

When the king had heard Gissur and Hjalti, he listened to reason and offered them the mission; he then took four hostages from the ranks of the Icelanders dwelling in Trondheim, whom he intended to detain until Christianity was legally accepted in Iceland, otherwise the hostages would be killed. Doubtless Gissur and Hjalti had a say in the choice of hostages; all of them were from the ranks of the chieftains, one from each quarter of the country: Kjartan Olafsson, Halldor Gudmundsson, Kolbeinn Thordarson and Svertingur Runolfsson. After this all the Icelanders in Trondheim accepted the faith and were baptized.

Gissur and Hjalti remained with the king during the winter and were well treated.

\section{b. Christianity legally accepted as the official religion of Iceland at the Althing}

In the spring of the year 1000, Gissur and Hjalti returned to Iceland with the king's commission and a considerable amount of money which the king had given them in order better to be able to influence the chieftains.

They arrived on June 19th and landed at the Westman Islands where they left timber for the construction of a church.

From the Westman Islands, they proceeded to Landeyjar, but received no assistance there as they were in the country of Runolfur the Godi of Dalur who was one of the main pagan leaders; they then continued over Thjors River up into Laugardal until they reached the Christians at Vellankatla, where they had planned to meet the previous summer.

The Christians then proceeded as a unified group to Thingvellir, sending word to their friends and relatives to meet them on the way. 
A large group rode to meet them. Among these were Asgrimur Ellidagrimsson and Thoroddur the Godi, who were both chieftains of the Arnes region; it is therefore clear that all the Godi from Arnes were supporters of Christianity.

It is hardly necessary to doubt that it came as a surprise to the pagans how great the number of Christians was, and how many had joined together on the way to the Althing; the conclusion may be drawn that the difference in size between the two groups was not overly great at this point, though the pagans were doubtless in the majority. It is not difficult to believe that many a man spent an uneasy night at Thingvellir; it is not improbable that messages went among many of those present, although this is not mentioned in the sources.

The story goes that the Christians, on the morning of June 23rd, went to the eastern end of the Almannagja, to the place later called Krossskard, Cross Gap, where they celebrated Mass; from there, they went to Lögberg (the Law Rock) where all the members of the assembly had gathered. There, Gissur and Hjalti stated their mission; there was much discussion and the heathens spoke against them. Gissur and Hjalti also spoke of their commission from the king; the contents of this mission are not mentioned in the sources, but they certainly spoke of the hostages which the king had taken at Trondheim.

It is clear that there was a great deal of noisy dissent when Hjalti, a condemned man, took the word; it is said that men, Christian as well as heathen, had disrupted the unity. Then there was disagreement about the eruption which threatened the farm of Thoroddur the Godi; Kristni saga states:

Then a man came running and said that an eruption had begun at Ölfus and that it would run to Thoroddur's farm. Then the heathen men spoke: 'It is no wonder that the gods have been angered by such speech.' 'Then Snorri the Godi spoke: 'What angered the gods then when the lava here under our feet burned?' (Kristnisaga 1905, 38 f.).

The two groups then gathered separately and the Christians chose Hallur of Sída as their law sayer and entrusted him to recount all the laws for the Christians in Iceland; the sources state that Hallur then met with Thorgeir the Godi of the Ljosvetnings who was at that time the official law sayer and requested that he pronounce the law for everyone, heathen as well as Christian (Kristnisaga 1905, 39). The wording ('keypt ad', literally 'bought to') is surprising, and the meaning seems not too clear; Hallur could have agreed that Thorgeir 
should say the law for the Christians and would be paid a fee for this office; it is also possible that it was agreed that Thorgeir would retain his position as Speaker of the Law, for the Christians as well, and would declaim one law for all Icelanders.

The story continues that Thorgeir returned to his tent, lay down under his fur cloak and remained there until the following morning. Thorgeir's actions as he lay under his cloak are disputed: some maintain that he conducted a heathen ritual to seek the answer of the gods (Aðalsteinsson 1971, $140 \mathrm{f}$.); others assert that he lay there and thought matters over, as he had to 'say' the laws the next morning and needed to take great pains about his speech if a split among the various groups were to be avoided (Aðalsteinsson 1971, 140 f.). Perhaps he isolated himself merely in order to get some peace to prepare his speech and free himself from the assiduous efforts of the arguing factions. Then, it has also been maintained that Thorgeir had other matters more important than lying down under his fur cloak to attend to: that he had, in the manner of diligent politicians everywhere and at all times, used this time to talk to people and build up support for his decision (Arnórsson 1941, 101 f.).

Of course, it is no longer possible to determine which conclusion is most near the mark.

The pagans also met and egged one another on; The sources mention human sacrifice (Kristnisaga 1905, 39 f.), but there is no indication that such sacrifice actually took place. The sources also mention a solemn promise made by the Christians at their meeting to the effect that they promised to devote their lives to Christ (Kristnisaga 1905, $4 \mathrm{f}$.), although there is no sign later that any such special vow was actually fulfilled.

On the morning of Monday June 24th, Thorgeir rose from under his fur cloak and invited those present to go to Lögberg and listen to his report; Kristni saga continues:

- (Thorgeir) said that unexpected matters had arisen in the country, that it was maintained that men should not have only one system of law, and he bade men not to do this, that such division would bring about battles and war and that would in turn open the way to laying waste of the land [...]

'And I think it reasonable not to allow those to decide who are most contentious, and offer as compromise therefore among them that each side has points in its favor, but we all must have one law and a single faith, because as it will be agreed: if we dissolve the law, we break the peace.' 
Thorgeir concluded that each side should agree that those laws which he spoke would be unanimously accepted.

Then Thorgeir decreed that all Icelanders should be baptized and that they should believe in one God. That the ancient laws about the exposure of children and consumption of horse meat should obtain; men could offer heathen sacrifice in secret if they wished, but would be outlawed under pain of death if such sacrifice were witnessed (Kristnisaga $1905,41 \mathrm{f}$.).

Not all of the participants of the Althing agreed with these decisions of Thorgeir's, but they bowed to them. They did not want to be baptized in the cold waters of Thingvellir's lake; they were therefore baptized in hot pools on their way home (Kristnisaga 1905, 42.).

In this way Christianity was accepted by law as the national religion of Iceland.

\section{Why did the Icelanders accept Christianity?}

As has been maintained elsewhere in this essay, the records of the events which led to the decision of the parliament to accept Christianity will hardly stand as they have been reported; it is absolutely clear that something is missing from them. In what follows the most likely sequence of events will be traced. First, it is necessary to try to explain as clearly as possible the structure of Icelandic society at the time of these events.

\section{a. Icelandic political structure}

The parliament, Althing, was established at Thingvellir in 930. It was decided that the highest power of the society should be in the hands of 36 chieftains who were called godi; their power was not merely bound by specific geographic districts; men could place themselves under the legal protection of the godi whom they wanted and whom they best trusted to protect their interests; the authority (godord) of the chieftain was therefore first and foremost leadership among men; the power of the godi was thus dependent on the size of his following; one could, in the same way, nullify one's agreement with a godi one did not like.

The godord were evenly distributed among the different parts of the country, such that there were nine in each quarter of the country. Before the convening of the Althing, three godi from the same district held a spring parliament for their own followers; the county system 
of modern Iceland is, to a significant extent, built on these spring parliamentary districts. The godord were inherited, but they could also be bought and sold. As time went on, one and the same man could control more than one godord.

The godord seemed, furthermore, to have had some sort of priestly function connected with it; the godi was responsible for holding sacrifices to the gods. It is clear then, that Christians were from the beginning locked out of all participation in the work of the Althing and consequently from participation in the governance of the country, and of course the upper class was almost completely heathen, when this governmental structure was put into effect. If a godi was baptized and became a Christian, he then, most probably by his own decision, gave up his seat in the legal council. The Christians must have been extremely unhappy about this political structure from the very beginning.

Others than the Christians must also have been unhappy with this division of power. There is no doubt that more than a mere 36 chieftains who sat at the law rock (Lögberg) had claims to power; they had been passed over because there was not sufficient room for them in the division of government; this fact is widely related in the Icelandic sagas, whatever value they have as sources in other matters.

The dissatisfaction seems to have been greatest in the northern part of Iceland, which was natural, as that was the most populous section of the country. The northerners had urged that the number of godord be increased in the north, but other godi stood strongly against them because more chieftains then could make demands for power. In addition, they wanted to keep the proportions of power distribution equitable among the various sections of the country.

In about 960 , there was an attempt to solve this problem by a change in the legislative structure. Iceland was divided into four quarters: three of them had nine godi each and they were sub-divided into three districts, each with three godi. The fourth quarter, the north, received three new godi so that the number of godi in the north was twelve; this was natural as the north was the most populous and divided naturally into four districts. The number of godi thus became thirty-nine, but in order not to disturb the balance of power among the quarters, the total number of godi was increased from 36 to 48 ; the godi from the three other quarters nominated three men from each section to sit at the Lögberg with them, without their obtaining a godord, however. In this way, the most serious problem, that concerning the northerners was remedied, but difficulties remained in other respects. There doubtless 
were many chieftains who considered themselves and their families to have been passed over in the division of power; and, of course, the Christians received no additional rights through this political solution.

Thus, it is clear that there was, from the beginning, great dissatisfaction among some of the chieftains with the division of political power; this discontent increased during the course of the tenth century. The dissatisfaction of the Christians must have increased particularly as their numbers grew around the end of the century. It seems clear that some of the chieftains who leaned towards Christianity became catechumens and did not take baptism, because, in this way, they could mingle with both groups, Christian as well as heathen, and retain their political power.

A few years after the acceptance of Christianity, another change was made in the political structure, when the so-called fifth court was legalized; it was decided that the old godi should sit on four-fifths of the court, but that one-fifth should be administered by those who were called the 'new' godi (Jólhannesson 1956, $90 \mathrm{f}$.). It seems obvious that this was some sort of compromise between the old and 'new' godi, and probably came about as a direct result of the events at the Althing on the acceptance of Christianity. It may be mentioned in conclusion that there are various sources extant about different district parliaments which fall outside the framework of those assemblies which were established by the ancient division; perhaps, the 'new' godi had attempted to mark off spheres of influence and power outside the actual system of government.

It may therefore be considered almost certain that a complete breakup had occurred in the Icelandic system of government shortly before the year 1000 and that there were disagreements between these two special interest groups, the old and 'new' godi. The group of the 'new' godi probably included almost all Christians excepting those from the group of the old godi who were converted just prior to the formal legal acceptance of Christianity; in addition, there were various pagans in this group who considered themselves to have been left out in the cold.

The old godi, on the other hand, wanted to protect their ancient rights; the Christian godi had doubtless supported them on this issue. They would have wanted to retain the main aspects of the former structure, though they of course wanted to obtain changes such that Christians could take full part in the government of the country; for this it was necessary there should be a complete distinction between the political structure and heathendom.

It may therefore be considered clear that quarrels existed between 
these two special interest groups without consideration of religious positions. This makes for an essential difference when one evaluates what happened at the Althing in the year 1000 .

It may also have been the case that Christians had even chosen Christian chieftains as godi; in this way some sort of 'religious godord' could have developed outside the political structure or alongside it. This could have had significant political influence, especially as the godord were not limited geographically.

\section{b. How was heathendom structured?}

Sources concerning the actual content of the heathen beliefs (ásatrú) which the Norse in Iceland professed are very few, as was previously explained. It is clear that the ásatrú was not a belief 'of the book' as Christianity is; it seems to have consisted first and foremost in specific religious customs and in the performance of certain religious functions; in other words, it was a 'kultus'. On the other hand, there are many indications that the real belief of the people was what might be called 'heimatru', or 'home belief', that is, it consisted of all sorts of spirits and folklore, which seems to have been very highly developed among the Icelanders. An example of this kind of beliefs is found in the story of the conversion of Kodrán, Thorvaldur's father.

The pagans seem to have generally been rather liberal in their religious attitudes as is commonplace among those who have a pantheon of gods; they had no difficulty in bringing new gods into the pantheon; they undoubtedly had difficulty in understanding the 'narrowmindedness' of the Christians who were allowed only one God.

On the other hand, the pagans held fast to their demand that the people participate in the public religious festivals if they wanted to take part in the power of the political system; they also refused to tolerate blasphemy toward the gods. Their attitudes in religious matters seem to have been similar to those of the ancient Romans; they did not bother about the religious ceremonies of the Christians, but demanded that they demonstrate their loyalty to the government by participation in the emperor worship, which was, in reality, much more a political ceremony than a religous one.

For this reason, it could hardly have been as difficult for heathens to accept Christianity as has sometimes been maintained; it is often forgotten that the ásatrú did not demand specific religious convictions as does Christianity. 
Heathen opposition to the Christian mission did not have merely religious roots. Christians were dangerous to the proper functioning of the government; they were outsiders who did not fit into the framework of the society and could therefore become dangerous revolutionaries who could threaten the peace and freedom of the country. Therefore, it was imperative to react sharply to their mission and increased influence, not least after a foreign monarch began to interfere.

The events, at the Althing in the final years before Christianity make this obvious; actual attempts were made to rebel against the ruling administration. These attempts at revolution were even more dangerous as it became clearer that the influence of the heathen beliefs was evaporating and religious dissolution increasing, not the least because of Christian influence; in this regard mention may be made of the poem "Völuspá", which was possibly composed at this time by a poet who had been significantly influenced by Christianity. The twilight of the gods seemed to be approaching and unrest made itself felt; people must have felt that fateful changes were imminent.

\section{c. What happened at the Althing in the year 1000?}

The Christians made vigorous attacts on the Icelandic political system at the parliaments of 998 and 999 , and every one was aware that a decisive crisis between Christians and pagans was approaching. The number of Christians was steadily increasing and their position growing steadily stronger. There is no doubt that both groups, Christian as well as heathen, had carefully considered plans of action.

The voyage of Gissur the White and Hjalti Skeggjason abroad has already been mentioned and there is little doubt that they were the representatives of the Christians, sent to meet with King Ólafur Tryggvason, who had shown great interest in the Christianization of Iceland, whether his primary concerns were religious or political; probably they were both. (Adam of Bremen is undoubtedly exaggerating when he says that some maintain that King Ólafur had, in the end, apostatized (Adam 1984, 93).)

The Icelandic Christians could hardly have been very pleased with the behaviour of the two missions which the king had sent to work in Iceland; they did not consider their methods reasonable. For this reason, they sent their representatives to meet with the king in order to come to terms with him as to how Christianity could best be brought to Iceland. 
Gissur and Hjalti concluded an agreement to this effect with King Ólafur during their winter in Trondheim; they most probably promised the king support in increasing his influence in Iceland, and it is quite natural that they wished to have help from the king in their dealings with the pagans; they therefore presented the king's cause at the Althing of the year 1000 .

Unfortunately, we have no idea what these errands were, but one hypothesis is that the king had demanded some sort of control in matters other than those merely religious. May it not be considered fortunate from an Icelandic political point of view that King Ólafur drowned off shore of Svoldur island that same autumn? It never came to the point that the Christians had to prove their loyalty to the king and the advancement of his political aims.

There is little doubt that the king's support of the Christians was greatly influential at the Althing. Icelanders were in close contact with Norway at this time. This is clearly indicated by, among other things, the number of important Icelanders who were staying in Norway that winter. The Icelanders realized after the voyages of Stefnir and Thangbrandur that the king would not stop until he had attained his goals in Iceland; in the end, the hostages in Trondheim doubtless took the heart out of the opposition of many toward Christianity, not the least among the friends and relatives of the hostages.

Undoubtedly, the pagans considered their position just as carefully as the Christians did; this is indicated, among other things, in the decision to delay the convening of parliament by one week in order to make it easier for those from outlying districts to arrive; they were consequently able to meet in great numbers.

It is tempting to hypothesize that cautious men among the godi of both groups groped for possible compromise which could successfully avoid complete political dissolution, or even civil war, within the country; the danger seems to have been overwhelming as subsequent events in dicate.

The members of the assembly came well prepared to the parliament that summer of 1000 . The division into groups was somewhat unclear beforehand, however. Doubtless the number of people who sided with the Christians came as a surprise to the heathens as they rode onto the site of Althing; in the group which sided with the Christians were many godi, and it was obvious that the old government structure had been thrown into disarray.

On the first day of parliament, June 23rd, violent and fomenting factions of both groups held the upper hand; they behaved in a bel- 
ligerent manner and seemed to be very ready to take up arms.

Subsequently, however, more reasonable men from both sides seem to have taken control, and they attempted to reach a compromise without a breach of the peace. In stead of Hjalti, who did most of the talking the first day, Hallur of Sída took control of the Christians, doubtless with the full support of Gissur the White and others of the godi who supported the Christians in these matters.

The Christians entrusted Hallur declaiming the laws for them and establishing in effect a separate state of Christians in Iceland. What would have been the consequences of this move? Unavoidable battles which would have slowly led to civil war in Iceland. Here it is necessary to point out that Christians and pagans lived, to a greater or lesser extent, among one another in most sections of the country, so that no natural borders could have been drawn between these two states; the situation could have become very like that which is currently found in Northern Ireland or in Lebanon.

It is not surprising, then, that the circumspect men who had control wanted individually to work to avoid such a chaotic possiblity; it was their united concern to keep the old power structure, if this was possible. In this they disagreed with the 'new' chieftains who felt left out and who worked diligently for change; the interests of Hallur and Gissur on the one hand and of Hjalti on the other by no means coincided on all matters.

Hallur met with Thorgeir the godi of the Ljósvetnings, the parliamentary speaker of the law and one of the foremost leaders of the pagans; there are various indications that they had previously discussed matters and tried to reach an agreement on what could be done to avoid total disorder. Hallur relinquished the position of speaker for the Christians and empowered Thorgeir to proclaim one law for all Icelanders, Christian as well as heathens; it is impossible that Hallur would have done this without knowing in advance what Thorgeir's decision was to be. It must have been obvious to all that the Christians would never agree to give up their religion and join the heathen; they were solemnly bound to Christ, who would never tolerate belief in any other gods.

The more moderate godi must have realized that the one way to keep the peace and the old order was for all of them to become Christians. This was a relatively easy decision for most of the chieftains, as can be seen from what has been previously mentioned about the nature of the heathen believes at this time; the devoted followers of the heathen gods were without any doubt in the distinct minority. 
Accordingly, the conclusion of these matters at the Althing was reached by the moderate leaders from both groups, those who wanted to work to protect the main aspects of the ancient political structure, besides wanting to keep the peace within the country and avoiding civil upheavals and bloody conflicts. Christian influence in the country had become so great by this time, that few could have been totally untouched by it.

The Norse mission which the authorities mention can in no way in and of itself fully explain the strength of the religion in Iceland, which is obvious in the way Christianity is legally accepted. Doubtless also included are the influences from the Christianity which existed in the country previous to the Norse settlement.

It is on the other hand conceivable that those who wrote down the history and who were loyal servants of the Roman Church had been greatly concerned to show that Christianity in Iceland in no way owed its origins to the Irish Church, which wanted to show that the Icelanders had been converted in the same way as the Norwegians; they were also concerned with crediting the king, Ólafur Tryggvason, with the conversion of the Icelanders.

\section{d. Critique of the sources}

The chief source for events leading to the conversion of the Icelanders and the legal acceptance of Christianity as a national religion is the priest Ari the Learned Thorgilsson, who has been considered a trustworthy source for these events because of his proximity to them and because of his connection with all those men who played a significant role in the events; he mentions some of his own sources; e.g., Teitur Isleifsson, who had in turn spoken with some of those who were present at the acceptance of Christianity at the Althing; Teitur was the grandson of Gissur the White; Ari himself was a fourth generation descendant of Hallur of Sída.

Ari seems, undeniably, to be a particularly one-sided source; he mentions mostly his own forefathers, and he doubtless heard primarily of them and their deeds; he particularly delineates sources from the south, but seems to be unknowledgeable about the history of others. Ari's bias could be unconscious; on the other hand, it can be maintained from his reports that he has specific points to make; e.g., in connection with the Roman Church, whether this stems from his own opinion or that of others. 
It is particularly notable that those chieftains who had accepted Christianity through the efforts of Thorvaldur and Frederich hardly play any role at all, as was mentioned previously.

\section{An attempted explanation}

Finally, a superficial explanation of the situation at the Althing that summer will be attempted here.

Is it known who were the most powerful chieftains in the year 1000 ?

Attempts have been made to draw up a list of those men who belonged to the legislature that year; some are known, others have been named on the basis of probability. In this way 40 chieftains have been proposed, who either had a godord or part of one, because these were sometimes divided among the chieftains (Arnórsson 1941, $83 \mathrm{ff}$.). In addition, the names of other Icelandic chieftains have been mentioned in reports of the acceptance of Christianity; and although not all of these owned a godord, they doubtless had influence in the parliament of that fateful summer. In this manner, the names of 52 chieftains who, in all probability, were or could have been at the Althing have been determined. Fourteen of these were from the eastern part of the country, 12 from the southern quarter, nine from the western part of the country and 17 from the north.

How did the parties divide into groups that summer?

There were of course two main groups, pagans and Christians. But that was not the only division, because two other parties, unconnected with religion, also existed; on the one hand, there were those circumspect and peace-loving leaders from the group of the godi who sat in the legislature and had the power and wanted to insure peace. On the other hand, there were those zealots who wanted to go to extremes and some of these were god $i$; still others stood outside the power structure and wanted to bring about changes in it.

How did these 52 chieftains who are thought to have been or who could have been at the parliament distribute themselves?

It is instructive to attempt to trace this division.

First, the Christians will be considered:

a. The circumspect Christians were: Hallur of Sída, Ingjaldur of Myrdal, Kolur Thorsteinsson, Önundur the Christian, Njall, Surtur, Gissur the White, Gestur Oddleifsson, Thorkell the Paw, Hlenni the Old and Thorvaldur Spakbödvarsson. Altogether 11 men. 
In addition to these there was a group of chieftains who were between Christianity and paganism and this group sided with the Christians at the Althing:

Össur of Broad River, Asgrimur Ellida-Grimsson, the nephew of Gissur the White, Thoroddur the Godi and Halldor llugason of Inner Holm, altogether four chieftains.

b. There was at least one Christian zealot, Hjalti Skeggjason, the son-in-law of Gissur the White.

So, 16 chieftains supported Christianity at the beginning of the Althing.

The pagans probably had a large majority at the opening of parliament, or as many as 36 supporters, but they were also divided into those who were cautious and those who were fanatics, even though this division is not absolutely evident.

\section{a. Circumspect heathens:}

Among these were the following influential leaders: Flosi Thordarson, Snorri the Godi, Olafur the Peacock, Asgeir the Hot Head, Kjartan Olafsson's father-in-law, Gudmundur the Rich Eyjolfsson, Einar of Thver River, his brother and Thorgeir the godi of the Ljosvetnings; there was, of course, a much larger number of these men, but we know for certain the names of these seven men, who were among the most powerful men in the country.

Five of these men hade close relatives among the hostages in Norway and probably joined forces with the Christians when they were informed of the taking of hostages. The other two, Snorri and Thorgeir, also tended in the same direction.

At last we hear of Ormur, brother of Thorvaldur the Widely Travelled, who joined the Christians. Altogether eight men.

Zealots among the heathens:

Among these we are certain of Runolfur Ulfsson of the Dale, who seemed at first to have been the leader in the opposition of the pagans; Valgardur, his uncle, supported him. They both undoubtedly relinquished their opposition when they learned that Svertingur Runolfsson was one of the hostages in Trondheim; this without doubt altogether lessened the power of the opposition to the Christian message.

Here we have ten who changed parties; then we have 26 chieftains who seem to have been Christian or had changed position and supported Christianity, and this is approximately one half of those chieftains who could have attended the Althing that summer. 
The position of the other chieftains is not known, although it is most likely that most of them were heathen, as was noted above; people hardly had interest in keeping alive the memory that their ancestors had been opposed to the legal acceptance of Christianity at the Althing. It is likely, however, that the majority of these were godi, and many of them doubtlessly belonged to the group of moderate chieftains who wanted above all to protect the division of power and the peace of the country. Some of them may therefore have changed party.

The number of godi was 39 ; at least 26 chieftains named above, not all of them godi, supported the Christian cause. There is little possibility of doubt where the main strength of the power lay at the Althing; it was in the party of the old and circumspect chieftains, many of whom were Christian or on the border between Christianity and heathenism, and some hade lifelong beloved friends who had already made up their minds.

The advice of Thorgeir the Ljosvetningagodi was followed at the Althing:

- it was agreed among them, that each side had valid points, but we have one law and a single tradition, because it is true: if we dissolve the law, then we destroy the peace (Kristnisaga 1905, 41).

It was the good fortune of the Icelandic nation that it went this way. Let us conclude here the discussion and enumeration of the events of the Althing in connection with the acceptance of Christianity.

\section{Conclusions}

The conclusion of this essay are, briefly, the following:

The first Icelandic settlers were Irish monks, papar but it is not known when they came to Iceland. There is also nothing known about their number, though this probably increased when the Norse began to harry the British Isles.

The Nordic settlement began then around 800, and increased during the ninth century; the Norsemen subjugated the land, but a few Christian settlements continued to exist. The Norse exercised complete political control and had many Christian slaves in their service. When the governmental structure was agreed upon in 930 at the founding of the Althing, it was closely tied to the heathen beliefs and Christians had no part in the governance of the country. 
No Christian mission was pursued among the Norse in Iceland before the latter part of the tenth century, and the ruling body of the Church took no part in this work. In the beginning, missionary activity was the private initiative of an Icelander, and the concluding chapter was supported by the Norwegian crown.

Christian influence increased steadily then during this heathen period. Christian slaves were often in charge of raising the children of chieftains, and there is little doubt that they had great influence of the religious attitudes of succeeding generations. In addition, it is very difficult to move local folk beliefs to a new country. Therefore it has been maintained that the position of heathen belief here in Iceland was too weak and feeble to defend itself against increasing Christian influences.

The greatest hindrance to the propagation of Christianity among the Icelandic chieftains during the tenth century was undoubtedly the fact that Christians were denied seats in the legislative assembly; therefore it was not easy for the sons of the chieftains to be converted.

Although pagans enjoyed a majority at the Althing in the year 1000 , the Christians had increased their numbers significantly and some godi were converted. There was great $d$ anger of war in the land if agreement were not reached at the assembly.

The choice consequently was either to reach an agreement or have a civil war, which would have led to the abrogation of the legal political and power structure. Older and peaceable chieftains wanted above all to protect the peace and they consequently accepted baptism and professed Christianity. No other option was possible.

This indicates that Christianity has had a great influence on Icelandic national life and that the formal conversion was not simply a political decision.

In the course of a few years, concessions at the time of conversion were revoked. During the latter part of the eleventh century, a cultural flowering, lastings for more than two centuries and producing, among other things, the Icelandic sagas, occurred in Iceland.

The Christian conversion at the Althing in the year 1000 was, thus, both a religious and a political decision. 


\section{Bibliography}

Aðalsteinsson, J. H. 1971. Kristnitakan á Íslandi. Reykjavík.

Adam af Bremen. 1984. Historien om Hamburgstiftet och dess biskopar. Stockholm.

Arnórsson, E. 1941. Kristnitökusagan árið 1000. Skírnir 119. Reykjavík.

Brennu-Njáls saga. 1954. [Ed. by] E. Ól. Sveinsson. (Íslenzk fornrit 12.) Reykjavík.

Dicuilus. 1967. Liber de Mesura Orbis Terre. Dublin.

Halldórsson, Ó. 1978. Granland í miðaldaritum. Reykjavík.

Hungrvaka. 1905. Kristnisaga, Dáttr Dorvalds ens vídforla [...]. Hrsg. von B. Kahle. (Altnordische Saga-Bibliothek 11.) Halle.

Íslendingabók. Íslendingabók. Landnámabók. 1968. [Ed. by] J. Benediktsson. (Íslenzk fornrit 1.) Reykjavík.

Jóhannesson, J. 1956. Saga Íslendinga 1. Reykjavík.

Kristnisaga. 1905. Kristnisaga, Dáttr Dorvalds ens vídforla [...]. Hrsg. von B. Kahle. (Altnordische Saga-Bibliothek 11.) Halle.

Landnámabók Íslands. 1948. Reykjavík.

Navigatio Sancti Brendani. 1973. (Lives of the Saints 10.) Middlesex.

Ólafs saga Tryggvasonar en mesta. 1958-61. [Ed. by] Ó. Halldórsson. (Editiones Arnamagnæana. Ser. A, 1-2.) København.

páttr Porvalds ens viðforla. 1905. Páttr Porvalds ens viðførla [...]. Hrsg. von

B. Kahle (Altnordische Saga-Bibliothek 11.) Halle. 